\title{
Pulmonary complications in patients undergoing coronary artery bypass grafting at a hospital in Maceio, Brazil
}

\section{Complicações pulmonares em pacientes submetidos à cirurgia de revascularização do miocárdio em um hospital de Maceió}

\author{
Ana Carolina do Nascimento Calles ${ }^{[a]}$, Jéssyca Lane Fausto Lira ${ }^{[a]}$, Karolyne Soares Barbosa Granja ${ }^{[a]}$, \\ Jaime Dativo de Medeiro ${ }^{[a]}$, Adoniran Rodrigues Farias ${ }^{[b]}$, Ricardo César Cavalcanti ${ }^{[c]^{*}}$ \\ [a] Centro Universitário Tiradentes (UNIT), Maceió, AL, Brazil \\ [b] Universidade Estadual de Ciências da Saúde de Alagoas (UNCISAL), Maceió, AL, Brazil \\ [c] Universidade Federal de São Paulo (UNIFESP), São Paulo, SP, Brazil
}

\begin{abstract}
Introduction: Despite technological advances aimed at reducing complications and hospital stay, pulmonary complications in the postoperative period of CABG surgery remain one of the most important causes of morbidity. These may be related to the patient's quality of life, the use of cardiopulmonary bypass, as well as a decline in postoperative respiratory muscle strength, contributing to the emergence of restrictive respiratory disorders. Objective: Assess pulmonary complications in patients undergoing coronary artery bypass graft surgery and identify their association with risk factors. Methods: A retrospective study with non-probability convenience sampling of 168 patients at the Hospital do Coração of Alagoas, undergoing CABG between January 2009 and October 2013. Results: The 168 patients undergoing CABG had a mean age of $60.08 \pm 10.03$ years, $24.4 \%$ women and $75.6 \%$ men. Among the cardiovascular risk factors were: Hypertension (89.9\%); Heredity for cardiovascular disease (54.8\%); Diabetes Mellitus (45.2\%); Dyslipidemia (41.1\%); Smoking (32.1\%); and Stroke (1.2\%). Pulmonary complications after surgery include pleural effusion (17.9\%); atelectasis (5.4\%); pneumothorax, pulmonary embolism, and acute respiratory
\end{abstract}

\footnotetext{
*ACNC: MS, email: carolina_calles@hotmail.com JLFL: BS, e-mail: jessycalane@live.com KSBG: undergrad, email: karolyne.soares@hotmail.com JDM: BS, email: jayme_medeiros@hotmail.com ARF: BS, email: adoniranfarias@globo.com RCC: MS, email: cavalcantirc@hotmail.com
} 
failure (1.2\%); and bronchopneumonia (0.6\%). Female patients and those aged 70 years or older experienced more pulmonary complications after surgery. Conclusion: Women and patients older than 70 years had the most severe postoperative pulmonary complications, the most common being pleural effusion and atelectasis.

Keywords: Myocardial Revascularization. Postoperative Complications. Frequency.

\section{Resumo}

Introdução: Apesar dos avanços tecnológicos, que visam diminuir as complicações e a permanência hospitalar, as complicações pulmonares no pós-operatório de cirurgia de revascularização do miocárdio (CRVM) continuam sendo uma das mais importantes causas de morbidade. Essas complicações pulmonares podem estar relacionadas com a qualidade de vida do paciente como ao uso da circulação extracorpórea, como também a diminuição da força muscular respiratória no pós-operatório que contribui para o surgimento de disfunções respiratórias restritivas. Objetivo: Avaliar as complicações pulmonares em pacientes submetidos à CRVM e identificar a sua associação com os fatores de risco. Métodos: Estudo retrospectivo por conveniência nãoprobabilística, onde foram estudados 168 pacientes no Hospital do Coração de Alagoas, submetidos à CRVM, no período de Janeiro de 2009 a Outubro de 2013. Resultados: Os 168 pacientes submetidos à CRVM, apresentaram idade média de 60,08 \pm 10,03 anos, sendo do gênero feminino 24,4\% e 75,6\% do gênero masculino. Dentre os fatores de risco cardiovascular, os pacientes apresentaram: Hipertensão Arterial Sistêmica 89,9\%, Hereditariedade para doença cardiovascular 54,8\%, Diabetes Mellitus 45,2\%, Dislipidemia 41,1\%, Tabagismo 32,1\% e Acidente Vascular Encefálico 1,2\%. Quanto ao comprometimento pulmonar após cirurgia: derrame pleural 17,9\%; atelectasia 5,4\%; 1,2\% para pneumotórax, embolia pulmonar e insuficiência respiratória pulmonar aguda; e 0,6\% broncopneumonia. As pacientes do gênero feminino e os pacientes com mais de 70 anos, apresentaram mais complicações pulmonares no pós-operatório. Conclusão: O gênero feminino e os pacientes com mais de 70 anos possuíram maiores complicações pulmonares pós-operatórias, sendo as mais frequentes derrame pleural e atelectasia.

Palavras-chave: Revascularização Miocárdica. Complicações Pós-Operatórias. Frequência.

\section{Introduction}

Cardiovascular diseases are the major cause of mortality, accounting for approximately $25 \%$ of deaths in developed countries, while in Brazil, atherosclerosis is responsible for around $40 \%$ (1). One way to improve the quality of life of patients affected by atherosclerosis is coronary artery bypass grafting (CABG). In the United States approximately 450.000 of these surgeries are performed every year, with mortality of around 8\% (1).

Patients submitted to cardiac surgery undergo a series of preoperative exams and tests, in order to guarantee intraoperative stability and good postoperative evolution. The procedure results in significant mortality and complications are related to the preoperative situation and extracorporeal circulation (ECC) used during the operation, requiring patients submitted to these procedures to be well prepared hemodynamically and psychologically for the postoperative period (2).

The saphenous vein is the most common material used to construct this new graft. The left internal mammary artery is also used because it is more resistant to atherosclerotic deposition than the coronary arteries themselves. The purpose of both grafts is to provide the blood supply necessary for contractile function. Coronary artery bypass graft surgery commences with a sternotomy, where the sternum (breastbone) is cut and separated with an appropriate device. After the sternum is opened and the soft tissues are separated, an incision is made in the pericardium, the membrane that surrounds the heart (3).

A number of researchers have shown the advantages of $\mathrm{CABG}$ without extracorporeal circulation (ECC) in relation to the procedure with ECC, primarily the lower postoperative mortality rates. This is because in surgeries without ECC there are fewer neurological disorders, respiratory complications, arrhythmias, deep sternal infections and low cardiac output syndromes, in addition to shorter orotracheal intubation times, better renal protection, less postoperative bleeding and fewer blood transfusions $(4,5)$. 
General anesthesia, surgical incision, extracorporeal circulation (ECC), ischemia time, degree of surgical manipulation, and number of pleural drains may predispose patients to changes in pulmonary function. After surgery, there is a decline in residual volume (RV), total lung capacity (TLC), vital capacity (VC) and residual functional capacity (RFC), prompting the formation of atelectasis from the lack of pulmonary insufflation, with changes in the ventilation-perfusion ratio $(\mathrm{V} / \mathrm{Q})$, and partial pressure of carbon dioxide $\left(\mathrm{PaCO}_{2}\right)$ in arterial blood (6).

As a result of sternotomy, significant alterations in pulmonary function due to chest wall instability lead to changes in ventilator mechanics and inefficient cough. The use of CEC and the absence of pulmonary ventilation during this period are also determining factors in the development of pulmonary complications after cardiac surgery, likely due to alterations in the mechanical properties of the respiratory system caused by changes in complacency and pulmonary resistance $(7,8,9)$.

In the event of compromised postoperative pulmonary function due to the aforementioned factors that predispose patients to develop respiratory complications, physical therapy plays an important pre and postoperative role in the treatment of patients submitted to cardiac surgery, aimed at creating more effective preventive strategies to reduce these complications (7).

The most common pulmonary complications are atelectasis and pleural effusion, which can occur in 20 to $70 \%$ of patients, as well as pneumonia, whose frequency varies with the residence time of the orotracheal tube, bronchospasm and lobar consolidation, present in $40 \%$ of patients, pulmonary edema, pleural effusion, pneumothorax and diaphragmatic dysfunction $(4,6)$.

Therefore, our primary objective is to assess these complications, frequently present in patients submitted to coronary artery bypass graft surgery, and identify their association with the risk factors.

\section{Methods}

This is a retrospective, descriptive, observational study with non-probability convenience sampling, conducted at the Hospital do Coração de Alagoas (HCOR-AL), between January 2009 and October 2013. The study was approved by the Research Ethics Committee of Tiradentes University, under protocol 453.963.
Data were collected from the medical charts of patients submitted to CABG at Hospital do Coração de Alagoas (HCOR). The charts were analyzed by researchers at HCOR, using a questionnaire created for the present study and containing the following variables: sex, age and cardiovascular risk factors including dyslipidemia (DLP), smoking, systemic blood pressure (SBP), diabetes mellitus (DM); transoperative complications, and pulmonary complications after CABG such as atelectasis, acute pulmonary edema (APE), pleural effusion, bronchopneumonia, pneumothorax and acute respiratory failure (ARF).

Given that this is a strictly observational study, data obtained from the patients' medical charts were analyzed. There was no diagnostic, therapeutic or any other type of intervention. All the data obtained in this study were kept confidential to ensure patient privacy.

The variables of the questionnaire were processed and stored in an Excel ${ }^{\circledR} 2010$ spreadsheet. Analysis was conducted by descriptive statistics (expressed in percentages, mean and standard deviation) and analytical statistics using Fisher's Exact test and the chisquared test, with a significant difference for $\mathrm{p}<0.05$.

Inclusion criteria

Patients submitted to coronary artery bypass surgery at Hospital do Coração de Alagoas, between January 2009 and October 2013.

\section{Exclusion criteria}

Patients submitted to any other surgery other than $\mathrm{CABG}$ and those requiring reoperation.

\section{Results}

A total of 168 patients were studied, 24.4\% (41) women and $75.6 \%$ (127) men. Mean age was $60.8 \pm$ 10.3 years.

The following cardiovascular risk factors were exhibited by the patients: SBP (89.9\%), heredity for cardiovascular disease (54.8\%), DM (45.2\%), Dyslipidemia (41.1\%), Smoking (32.1\%) and Stroke (1.2\%).

Complications observed after CABG were: other non-pulmonary complications such as prolonged CEC, hemodynamic instability such as arrhythmias and acute myocardial infarction (AMI), thrombotic events, hemorrhages, postoperative infections, cardiorespiratory 
arrest (CPA), acute kidney failure, stroke (69.6\%), pleural infusion (17.9\%), atelectasis (5.4\%), pneumothorax $(1.2 \%)$, pulmonary edema $(1.2 \%)$, acute respiratory failure $(1.2 \%)$, and bronchopneumonia $(0.6 \%)$, as illustrated in Figure 1.

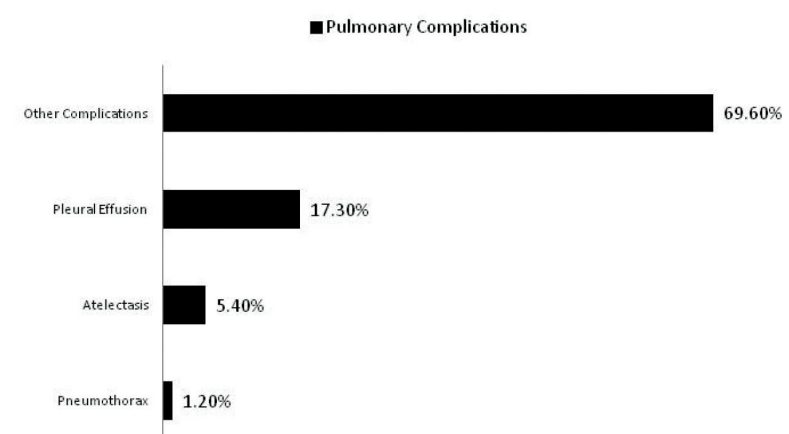

Figure 1 - Percent distribution of complications after CAGB.

When complications are compared by sex, $34.1 \%$ of the 41 women and $12.6 \%$ of the 127 men exhibited pleural effusion. The remaining complications showed no significant differences between the sexes ( $p>0.05$ ), as demonstrated in Figure 2.

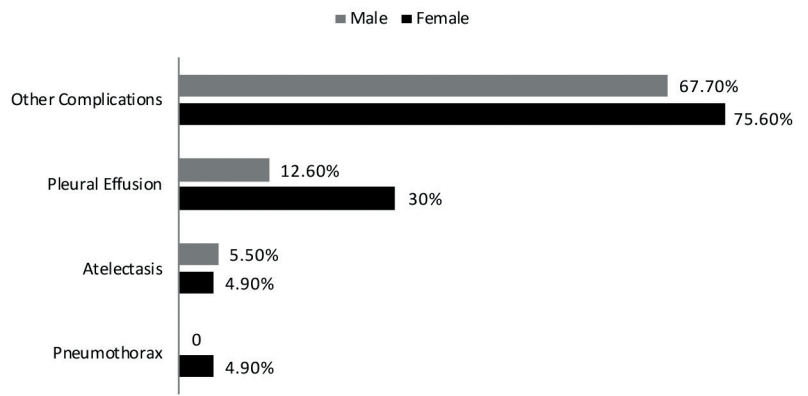

Note: research data.

Figure 2 - Percent distribution of the correlation between complications and sex.

In the correlation between complications and age range, it was only possible to apply the chi-squared test for pleural effusion and other complications, due to the low number of cases for some complications. Pleural effusion showed no significant difference with respect to age range $(p>0.05)$. There was a significant difference for other complications ( $\mathrm{p}<0.05)$. Of the $30 \mathrm{pa}-$ tients 70 years of age or older, $86.7 \%$ exhibited other complications. Of the 114 patients between 50 and 70 years of age, $69.3 \%$ displayed other complications, and of the 24 patients aged between 30 and 50 years, $50.0 \%$ had other complications, as shown in Figure 3.

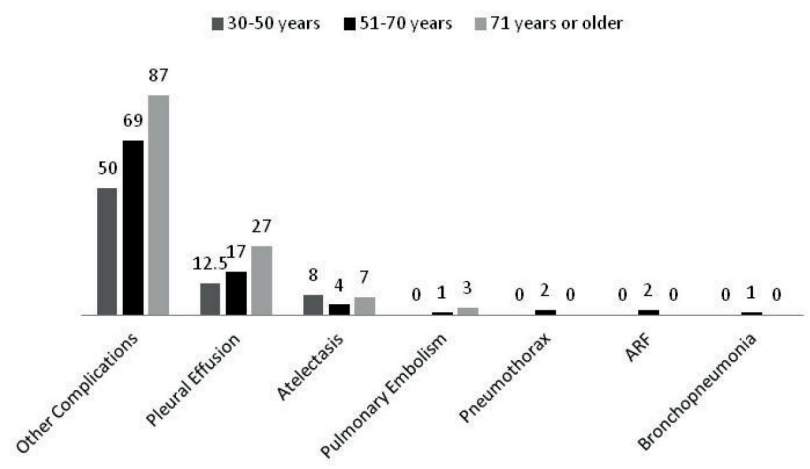

Note: research data.

Figure 3 - Percent distribution of the correlation between complications and age range

When complications are correlated with cardiovascular risk factors, there was a significant difference only between atelectasis and heredity $(\mathrm{p}<0.05)$. Of the 92 patients with this risk factor, $8.7 \%$ exhibited atelectasis, while only $1.3 \%$ of the 76 who did not have this risk factor displayed atelectasis. For the remaining complications, there was no significant difference $(p>0.05)$, as depicted in Figure 4.

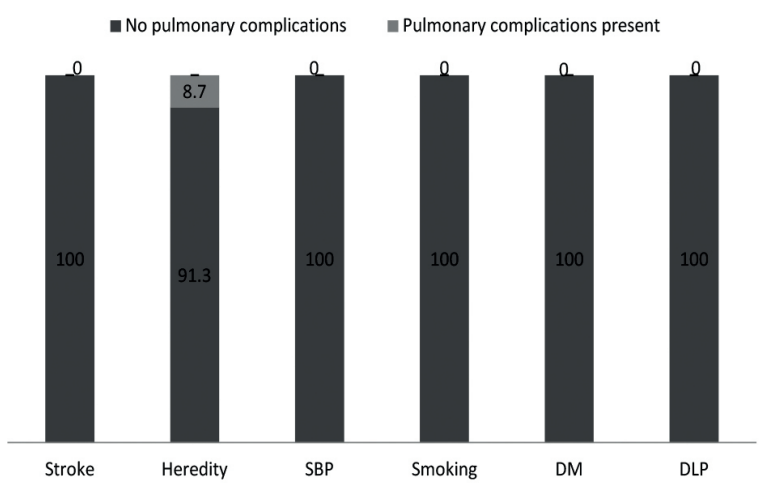

Figure 4 - Percent distribution of the correlation between complications and cardiovascular risk factors 


\section{Discussion}

In CAGB, irrespective of the technique used, there is a decline in pulmonary function in the early postoperative period. Evidence demonstrates that pulmonary complications occur in 20 to $65 \%$ of patients submitted to this procedure (10).

Regardless of other factors, general anesthesia, added to surgery, is responsible for altering postoperative pulmonary function, given that the former promotes depression in the respiratory centers, that is, the longer the sedation time, the greater the risk of pulmonary compromise (11).

In our study there was a significant difference between the sexes, corroborating other studies showing that $70.7 \%$ of patients were men and $29.3 \%$ women (11); Blattner et al. (4) found $60 \%$ men and $40 \%$ women.

Recent research showed that women have higher CAGB-related mortality rates than men. The increased risk for complications and mortality in cardiac surgery in women is attributed to the following factors: smaller body surface, smaller arterial diameter, and a decline in estrogen with age (12).

With respect to age, we found a similar mean to that reported in other studies, namely $62.50 \pm$ 9.52 years (11) and $60.10 \pm 5.56$ years (10).

The present study, in line with other investigations $(13,14,15,16)$, shows that postoperative morbidity is significantly higher in patients aged 70 years or older. In our sample, patients in this age group that underwent CAGB had more pulmonary complications in postoperative hospitalization compared to younger individuals.

In this respect, age is one of the factors to consider for both complications and mortality, primarily when associated with the use of invasive mechanical ventilation (IMV), reaching $92 \%$ in individuals older than 75 years. The daily ICU costs for these patients are seven-fold higher than for individuals under 65 years of age $(17,18)$.

This study also demonstrated that these complications are closely related to preoperative risk factors such as SBP, Heredity for cardiovascular disease, DM, Dyslipidemia, and Smoking, corroborating another investigation that showed an $88.3 \%$ prevalence of SBP, history of dyslipidemia (66.4\%), DM (32.9\%) and smoking (56.6\%) in patients submitted to CAGB (13). The main risk factors for the emergence of postoperative alterations are age, sex, and preexisting pathologies $(19,20)$.

SBP is a well-established risk factor for cardiovascular disease and congestive heart failure. Coronary heart disease occurs more commonly in diabetics than in the general population, affecting more than $55 \%$ of patients, making it the greatest risk factor for cardiovascular disease (21).

According to a number of studies, smoking also plays an important role in the development of coronary artery disease. However, this influence depends on sex, that is, this factor has a clear impact on men (22).

In our result, the most frequent postoperative pulmonary complications were pleural effusion and atelectasis, confirming another study that showed pleural effusion frequency of $84 \%$ and atelectasis of $65 \%$ (8). The frequency of pulmonary complications is high after CAGB, reaching $40 \%$, contributing to patient morbidity and mortality, increased hospitalization times and a rise in hospital costs $(23,24)$.

The use of drains and their location, especially in the pleural region, may be related to pleural lesions during removal of the internal mammary artery during surgery. Thus, drain use may be associated with the decline in pulmonary function, by increasing respiratory work through alterations in gas exchanges and pulmonary mechanics, and decreasing pulmonary volumes, thereby predisposing patients to secretion accumulation and possible airflow obstruction, resulting in the emergence of atelectasis $(25,26)$.

Thus, in addition to technological advances, better clinical observation is needed to detect possible cardiovascular risk factors, in order to reduce postoperative complications and hospitalization time, increasingly improving the condition of postoperative patients.

\section{Conclusion}

The present study showed a prominence of male patients submitted to CAGB. However, female patients at advanced ages exhibited higher rates of pulmonary complications, the most common being pleural effusion and atelectasis, while the most prevalent cardiovascular risk factor was SBP. 


\section{References}

1. Magedanz EH, Bodanese LC, Guaragna JCVC, Albuquerque LC, Martins V, Minossi SD, et al. Elaboração de escore de risco para mediastinite pós-cirurgia de revascularização do miocárdio. Rev Bras Cir Cardiovasc. 2010;25(2):154-9.

2. Laizo AF, Delgado EF, Rocha GM. Complicações que aumentam o tempo de permanência na unidade de terapia intensiva na cirurgia cardíaca. Rev Bras Cir Cardiovasc. 2010;25(2):166-71.

3. Santana CAA. Cirurgia de revascularização do miocárdio: mudanças vividas pelos pacientes e sua opinião sobre o papel do fisioterapeuta na reabilitação [master's thesis]. Belo Horizonte (Brazil): Universidade do Estado de Minas Gerais, Fundação Educacional de Divinópolis; 2008. Portuguese.

4. Blattner CN, Saadi EK. Efeito da fisioterapia respiratória precoce em pacientes no pós-operatório imediato de cirurgia de revascularização do miocárdio e seu impacto clínico [master's thesis]. Porto Alegre (Brazil): Universidade Federal do Rio Grande do Sul; 2008. Portuguese.

5. Navia D, Vrancic M, Vaccarino G, Piccinini F, Iparraguirre E, Casas M, et al. Cirurgia coronária com condutos arteriais múltiplos sem circulação extracorpórea. Rev Bras Cir Cardiovasc. 2005;20(1):39-45.

6. Romanini W, Muller AP, Carvalho KA, Olandoski M, Faria-Neto JR, Mendes FL, et al. The effects of intermittent positive pressure and incentive spirometry in the postoperative of myocardial revascularization. Arq Bras Cardiol. 2007;89(2):94-9.

7. Morsch KT, Leguisamo CP, Camargo MD, Coronel CC, Mattos W, Ortiz LDN, et al. Perfil ventilatório dos pacientes submetidos a cirurgia de revascularização do miocárdio. Rev Bras Cir Cardiovasc. 2009;24(2):180-7.

8. Szeles TF, Yoshinaga EM, Alencar W, Brudniewski M, Ferreira FS, Auler Jr JOC, et al. Hipoxemia após revascularização miocárdica: análise dos fatores de risco. Rev Bras Anestesiol. 2008;58(2):124-36.

9. Malbouisson LMS, Brito M, Carmona MJC, Auler Jr JOC. Impacto hemodinâmico de manobra de recrutamento alveolar em pacientes evoluindo em choque cardiogênico no pós-operatório imediato de revascularização do miocárdio. Rev Bras Anestesiol. 2008;58(2):112-23.
10. Guizilini S, Bolzan DW. Faresin SM, Alves FA, Gomes WJ et al. Miniesternotomia na cirurgia de revascularização miocárdica preserva função pulmonar pós-operatória. Arq Bras Cardiol. 2010; 95(5):587-93.

11. Ortiz LDN, Schaan CW, Leguisamo CP, Tremarin K, Mattos WLLD, Kalil RAK. Incidência de Complicações Pulmonares em Cirurgia de Revascularização do Miocárdio. Rev Bras Cir Card. 2010;95(4): 441-7.

12. Sá MP, Lima LP, Rueda FG, Escobar RR, Cavalcanti PE, Thé EC, et al. Comparative study between on-pump and offpump coronary artery bypass graft in women. Rev Bras Cir Cardiovasc. 2010;25(2):238-44.

13. Alves Jr L, Rodrigues AJ, Évora PRB, BassetoI S, Scorzoni Filho A, Luciano PM, et al. Fatores de risco em septuagenários ou mais idosos submetidos à revascularização do miocárdio e ou operações valvares. Rev Bras Cir Cardiovasc. 2008;23(4).

14. Campagnucci VP, Silva AMRP, Pereira WL, Chamlian EG, Gandra SMA, Rivetti LA. EuroSCORE e os pacientes submetidos a revascularização do miocárdio na Santa Casa de São Paulo. Rev Bras Cir Cardiovasc. 2008;23(2):262-7.

15. Guaragna JC, Facchi LM, Baião CG, Cruz IBM, Bodanese LC, Albuquerque L, et al. Preditores de mediastinite em cirurgia cardíaca. Rev Bras Cir Cardiovasc. 2004;19(2):165-70.

16. Alves Jr L, Rodrigues AJ, Evora PRB, Basseto S, Scorzoni Filho A, Luciano PM, et al. Fatores de risco em septuagenários ou mais idosos submetidos a revascularização do miocárdio e ou operações valvares. Rev Bras Cir Cardiovasc. 2008;23(4):550-5.

17. Feijó CAR. Morbimortalidade do idoso internado na unidade de terapia intensiva de um Hospital Universitário de Fortaleza. Rev Bras Ter Intensiva. 2006;18(3):263-7.

18. Michalopoulos A, Tzelepis G, Dafni U, Geroulanos S. Determinants of hospital mortality after coronary artery bypass grafting. Chest. 1999;115(6):1598-603.

19. Oliveira JMA, Silva AMF, Cardoso SB, Lima FF, Zierer MS, Carvalho ML. Complicações no pós-operatório de cirurgia cardiovascular com circulação extracorpórea. Rev Interd. 2015;8(1):9-15.

20. Torrati FG, Danta RAS. Circulação extracorpórea e complicações no período pós-operatório imediato de cirurgias cardíacas. Acta Paul Enferm. 2012;25(3):340-5. 
21. Kaufman R, Kuschnir MCC, Xavier RMA, Santos MA, Chaves RBM, Müeller RE, et al. Perfil epidemiológico na cirurgia de revascularização miocárdica. Rev Bras Cardiol. 2011;24(6):369-76.

22. Barros GF, Santos CS, Granado FB, Costa PT, Límaco RP, Gardenghi G. Treinamento muscular respiratório na revascularização do miocárdio. Rev Bras Cir Cardiovasc. 2010;25(4):483-90.

23. Ambrozin ARP, Vicente MMT. Associação entre o tempo de ventilação mecânica no pós-operatório de revascularização do miocárdio e as variáveis de risco pré-operatório. Ensaios Cienc, Cienc Biol Agrar Saude. 2008;12(1):113-29.

24. Filardo FA, Faresin SM, Fernandes LG. Validade de um índice prognóstico para ocorrência de complicações pulmonares no pós-operatório de cirurgia abdominal alta. Rev Assoc Med Bras. 2002;48(3):209-16.

25. Moustafa MA, Abdelsamad AA, Zakaria G, Omarah MM. Minimal versus median sternotomy for aortic valve replacement. Asian Cardiovasc Thorac Ann. 2007;15(6):472-5.

26. Soares GMT, Ferreira DCS, Gonçalves MPC, Alves TGS, David FL, Henriques KMC, et al. Prevalência das Principais Complicações Pós-Operatórias em Cirurgias Cardíacas. Rev Bras Cardiol. 2011;24(3):139-46.

Received in $07 / 28 / 2014$

Recebido em 28/07/2014

Approved in 11/09/2015

Aprovado em 09/11/2015 
